Gut, 1973, 14, 438-443

\title{
Liver structure and function following small bowel resection
}

\author{
M. C. GUPTA ${ }^{1}$, GRAHAM NEALE, AND R. HERMON DOWLING ${ }^{2}$
}

From the Department of Medicine and MRC Intestinal Malabsorption Group, Royal Postgraduate Medical School, Ducane Road, London

SUMMARY The observation that patients with extensive small bowel resection have impaired hepatocellular function with reduced BSP clearance and fatty change in biopsies from the liver led to a systematic study of liver structure and function following proximal and distal small bowel resection in the rat.

While anaesthesia and surgery impaired BSP clearance per se, small bowel resection further reduced BSP clearance with impairment of both uptake and excretion phases of BSP excretion.

The increased BSP retention was more marked after distal than after proximal small bowel resection, but in both experimental groups the abnormalities of BSP excretion spontaneously returned to normal three to four weeks after surgery.

Circulating liver enzymes were normal but serum alkaline phosphatase was significantly depressed, particularly after distal resection. Isoenzyme studies showed that the depression of serum AP was due to a reduced intestinal isoenzyme. While serum levels remained consistently depressed up to eight weeks after proximal resection, in parallel with mucosal regeneration, serum AP returned to normal two to four weeks after ileectomy.

While these minor changes in hepatic structure and function would normally be of little clinical importance, the additional insult of hepatic dysfunction may well be important in malnourished patients after extensive small bowel resection.

Small bowel bypass operations, performed in the treatment of obesity or hypercholesterolaemia, may be complicated by hepatic dysfunction (Lewis, Turnbull, and Page, 1962; Payne, DeWind, and Commons, 1963; Koenemann and Ceballos, 1966; Shibata, MacKenzie, and Long, 1967; Bondar and Pisesky, 1967; Maxwell, Richards, and Albo, 1968), and even by hepatic coma and death (Barron, Frame, and Bonzalis, 1969; Shagrin, Frame, and Duncan, 1971; Humphreys, Dickson, Bagenstoss, and McGill, 1972). However, little is known about liver structure and function following small bowel resection, and whereas occasional case reports have described hepatic dysfunction as a complication of intestinal resection, except for one limited study in

1Present address: J.N. Medical College, AMU, Aligarh, India

${ }^{2}$ Requests for reprints to R.H.D.

Received for publication 23 March 1973. the rat (Derblom, Nylander, and Olerud, 1962), there have been no systematic studies of liver structure and function after resection.

The observation that six patients with extensive small bowel resection had transient changes in bromsulphthalein (BSP) clearance, and in hepatocellular function with morphological changes on needle biopsy of the liver, led to a systematic study of hepatic function three days to six weeks after resection of two-thirds of proximal or distal small bowel in the rat. This paper describes the clinical findings and presents the results of the experimental animal studies.

\section{Materials and Methods}

THE PATIENTS

Clinical details of the six patients studied together with the results of their liver function tests are given in the table. 


\begin{tabular}{|c|c|c|c|c|c|c|c|c|c|c|}
\hline \multirow[t]{2}{*}{ Patient } & \multirow{2}{*}{$\begin{array}{l}\text { Age \& } \\
\text { Sex }\end{array}$} & \multirow[t]{2}{*}{ Extent of Resection } & \multirow{2}{*}{$\begin{array}{l}\text { Time after } \\
\text { Resection } \\
\text { when } \\
\text { Studied }\end{array}$} & \multicolumn{7}{|c|}{ Liver 'Function' Tests } \\
\hline & & & & $\begin{array}{l}\text { Serum } \\
\text { Albumin } \\
\text { (g/100 ml) } \\
\text { (Means \& } \\
\text { Ranges) }\end{array}$ & \multicolumn{3}{|c|}{ Hepatocellular Enzymes } & \multicolumn{2}{|c|}{ Biliary Tree Enzymes } & $\begin{array}{l}\text { BSP Retention } \\
\text { at } 45 \text { Minutes } \\
(N<5 \%)\end{array}$ \\
\hline 1 & M 44 & $\begin{array}{l}1 \frac{1}{2} \text { in }(4 \mathrm{~cm}) \text { jejunum } \\
\text { anastomosed } \\
\text { to } 2 \frac{1}{2} \text { in }(6 \mathrm{~cm}) \text { ileum }\end{array}$ & $7-12$ wk & $2 \cdot 0-2 \cdot 8$ & $11-15$ & 一 & 105 & 6 & 一 & $27 \rightarrow 16 \%$ \\
\hline 2 & F 50 & $\begin{array}{l}6 \text { in }(15 \mathrm{~cm}) \text { jejunum } \\
\text { anastomosed to } \\
\text { transverse colon }\end{array}$ & $5-7 \mathrm{mth}$ & $\begin{array}{l}3 \cdot 4 \\
(2 \cdot 7-4 \cdot 1)\end{array}$ & $\begin{array}{l}25 \\
(13-66)\end{array}$ & $34 \rightarrow 3$ & $\begin{array}{l}213 \\
(305 \rightarrow 180)\end{array}$ & $\begin{array}{l}17 \\
(11-34)\end{array}$ & $\begin{array}{l}28 \\
(90 \rightarrow 10)\end{array}$ & $23 \rightarrow 5 \%$ \\
\hline 3 & F 58 & $\begin{array}{l}11 \mathrm{ft}(335 \mathrm{~cm}) \text { distal } \\
\text { small bowel resected; } \\
\text { jejuno-transverse } \\
\text { anastomosis }\end{array}$ & $3 \frac{1}{2}$ yr & $3 \cdot 9-4 \cdot 0$ & $21-24$ & 7 & 110 & $4-8$ & 3 & 3 \\
\hline 4 & M 48 & $\begin{array}{l}18 \text { in }(46 \mathrm{~cm}) \text { jejunum } \\
\text { anastomosed to } \\
\text { caecum }\end{array}$ & 4-10 wk & $3 \cdot 3$ & 一 & 5 & - & 7 & 一 & $24 \rightarrow 17 \rightarrow 5 \%$ \\
\hline 5 & F 37 & $\begin{array}{l}7 \text { in }(18 \mathrm{~cm}) \text { jejunum } \\
\text { anastomosed to } 5 \text { in } \\
(13 \mathrm{~cm}) \text { ileum }\end{array}$ & $8-10$ wk & $4 \cdot 2$ & 55 & $15 \rightarrow 8$ & - & $17 \rightarrow 6$ & 一 & $16 \rightarrow 7 \%$ \\
\hline 6 & M 76 & $\begin{array}{l}14 \text { in }(36 \mathrm{~cm}) \text { jejunum } \\
\text { anastomosed to } \\
\text { transverse colon }\end{array}$ & 6-12 wk & $\begin{array}{l}3 \cdot 0 \\
(2 \cdot 3-3 \cdot 6)\end{array}$ & 一 & 3 & 一 & 16 & 2 & $\begin{array}{l}33 \rightarrow 22 \rightarrow \\
15 \rightarrow 14 \rightarrow \\
18 \rightarrow 6 \%\end{array}$ \\
\hline
\end{tabular}

Table Clinical details and results of liver 'function' tests in six patients with extensive small bowel resection

EXPERIMENTAL ANIMALS

Adult male Wistar rats weighing between 140 and $200 \mathrm{~g}$ at the time of operation were used throughout. There were two experimental and two control groups. In the experimental animals, approximately twothirds of either proximal or distal small intestine was resected as previously described (Dowling and Booth, 1967). The control groups consisted of unoperated rats and sham operated animals in which the mid small bowel was simply divided and reanastomosed. Only those animals with an uncomplicated recovery from surgery and which were gaining weight satisfactorily were selected for further investigations. This selection was made in order to study the effects of resection per se without the additional complications of malnutrition or intercurrent infection. There were 20 such rats in each group.

\section{LIVER FUNCTION IN THE RAT}

Liver function in the resected and control groups was assessed by measuring: (a) the kinetics of BSP clearance from the plasma in 12 rats from each group, at four days and at one, two, three, and four weeks after surgery, and (b) circulating 'liver' enzymes in eight rats from each group, between four days and eight weeks after operation.

\section{BSP clearance}

The clearance of a standard rat dose of BSP (50 $\mathrm{mg} / \mathrm{kg}$ ) was measured in rats lightly anaesthetized with ether. Serial $0.3 \mathrm{ml}$ blood samples were taken from the external jugular vein into heparinized tubes at one, three, five, 10, 20, and 40 minutes. Bromsulphthalein was estimated by the method of Seligson, Marino, and Dodson (1957) using $0.1 \mathrm{ml}$ plasma and $3.0 \mathrm{ml}$ alkaline buffer.

\section{Circulating liver enzymes}

Two predominantly hepatocellular enzymes, serum glutamic oxalo-acetic transaminase (SGOT) and lactic acid dehydrogenase (LDH), and two 'biliary tree' enzymes, alkaline phosphatase (AP) and gamma glutamyl transpeptidase (GGT), were measured using routine laboratory micromethods. In addition, the isoenzymes of alkaline phosphatase were measured quantitatively by heat inactivation and starch gel electrophoresis (Poulik, 1957).

\section{LIVER HISTOLOGY IN THE RAT}

Two animals from each group were sacrificed at one, two, and four weeks and representative blocks of liver were taken for histological examination. Seven micron thick sections were taken from each block and stained with haematoxylin and eosin.

\section{Results}

THE PATIENTS

\section{Liver function}

The results of the liver function tests are given in the table. The most consistent abnormality was im- 
paired BSP clearance. With the exception of patient no. 3, who was studied three and a half years after resection, all the patients initially had increased BSP retention. In one patient (no. 1), in whom the kinetics of BSP clearance were studied, both the uptake and excretion phases appeared equally impaired. In every case, the impaired BSP clearance improved spontaneously with time, usually returning to normal levels (fig 1).

Two patients had moderately raised serum alkaline

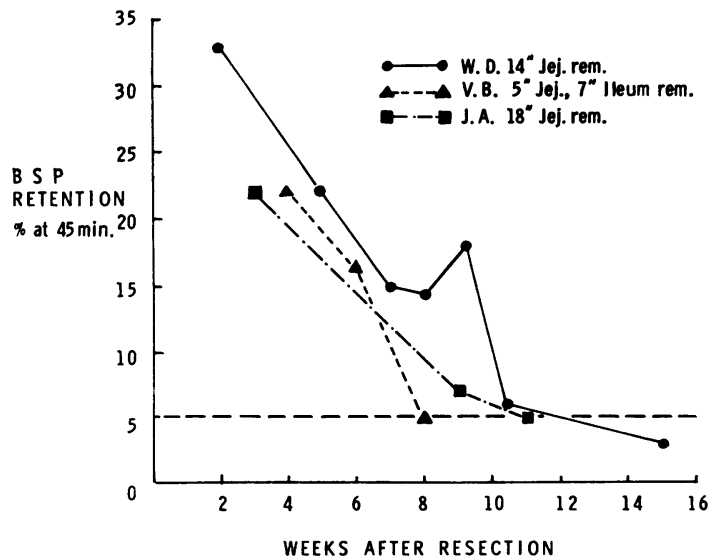

Fig 1 Results of 45-min BSP retention after $5 \mathrm{mg}$ $B S P / k g$ body weight by intravenous injection in three patients with extensive small bowel resection. The increased retention seen in the first few weeks after resection returned towards normal spontaneously with time. phosphatase levels, and while one of these had a corresponding rise in $5^{\prime}$-nucleotidase levels (patient no. 2), her alkaline phosphatase isoenzymes showed a raised bone component; she subsequently proved to have subclinical osteomalacia.

\section{Liver biopsy}

In general, the normal hepatic lobular architecture was well preserved and there was no evidence of fibrosis or cirrhosis. However, in four out of five liver biopsies there was mild to moderately severe centrilobular fatty change. In addition, the biopsy from one patient showed minimal evidence of necrosis with the disappearance of groups of two to three hepatocytes. The biopsy from another patient showed a mild, non-specific hydropic degeneration and excessive numbers of mitoses, but these changes were not seen in any of the other biopsies.

\section{EXPERIMENTAL ANIMALS}

Liver function in the rat: bromsulphthalein clearance The 40-minute BSP retention results in the four groups of animals are shown in figure 2. At four days after operation, the mean BSP retention for control animals was $0.86( \pm$ SEM 0.17$) \%$ of the injected dose. Both groups of resected rats showed significantly increased BSP retention which was more marked after distal resection $(2.40 \pm$ SEM $0.28 \%)$ than after proximal resection ( $2 \cdot 17 \pm$ SEM $0 \cdot 28 \%)$.

The non-specific effects of fasting, anaesthesia, and surgery were also associated with slight impairment of BSP excretion as seen in the transected control group in which the mean 40-minute retention at

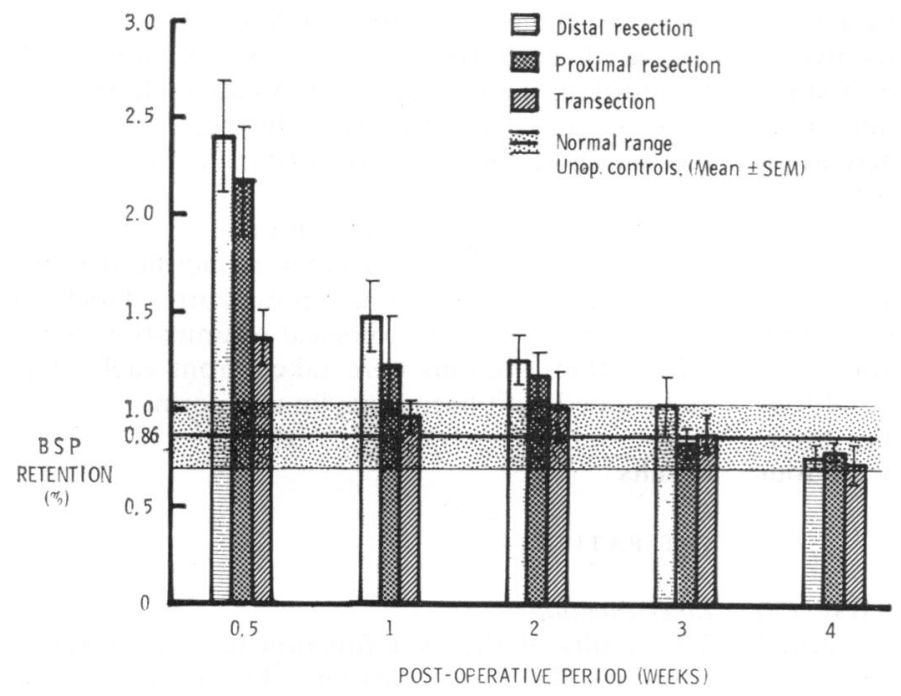

Fig 2 Forty-min BSP retention after $50 \mathrm{mg} \mathrm{BSP} / \mathrm{kg}$ body weight by intravenous injection in rats with proximal or distal small bowel resection, in rats with intestinal transection, and in unoperated control animals between 0.5 and four weeks after operation. The significantly increased BSP retention in the resected animals spontaneously returned to normal at three and four weeks after surgery. 


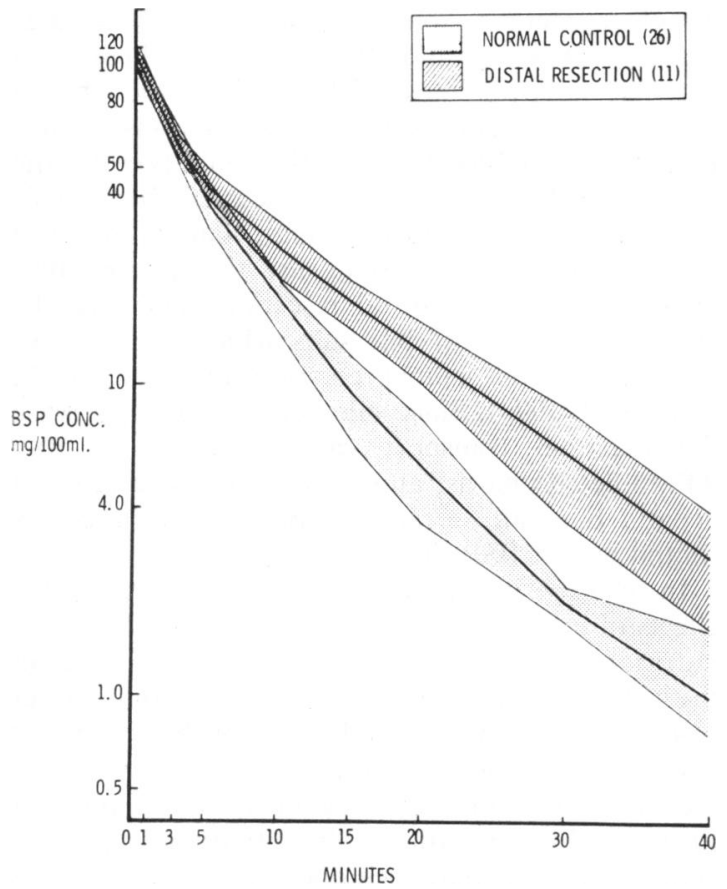

Fig 3 Kinetics of plasma BSP clearance in 26 control rats (means $\pm S E M$ ) and in 12 rats 0.5 week after proximal small bowel resection. Similar disappearance curves were obtained from studies of rats after distal resection.

four days after operation was $1 \cdot 37 \pm \operatorname{SEM} 0 \cdot 14 \%$. However, this non-specific effect was only seen immediately after surgery and by one week there were no significant differences between the transected and unoperated control groups.

In contrast, abnormal BSP retention persisted in the resected animals, although, as in the clinical studies, the impaired BSP excretion spontaneously returned to normal with time. In the distal resection group, the 40-minute retention value at one week was $1.48 \pm 0.18 \%$, at two weeks $1.25 \pm 0.12 \%$, and at three weeks $1.04 \pm 0 \cdot 17 \%$. The corresponding figures for rats with a proximal resection were 1.23 \pm $0.25 \%, 1 \cdot 20 \pm 0.13 \%$, and $0.80 \pm 0.11 \%$.

In order to assess the excretion of BSP in more detail, plasma disappearance curves were constructed for each experiment. In all three operated groups, the impaired BSP clearance from plasma was apparent within five minutes of giving the injection (fig 3).

\section{Serum enzymes after intestinal resection}

In spite of the changes in BSP clearance, the circulating 'liver' enzymes (SGOT and LDH) did not increase following small bowel resection. Surprisingly, the converse was found for alkaline phosphatase levels, which decreased significantly immediately after resection. Starch gel electrophoresis suggested that this fall in circulating AP activity was due to a reduction of the intestinal isoenzyme fraction. In animals with distal resection, the serum AP levels returned to normal within three weeks, but in the proximal resection group, no such 'compensation' occurred and even eight weeks after jejunectomy, the AP levels remained significantly less than control values. Mean values of circulating GGT were also lower in rats with proximal small bowel resection, although the differences from controls were not statistically significant.

\section{Histology}

Light microscopy did not reveal any morphological differences in the sections of the liver obtained from resected animals compared with controls. There was

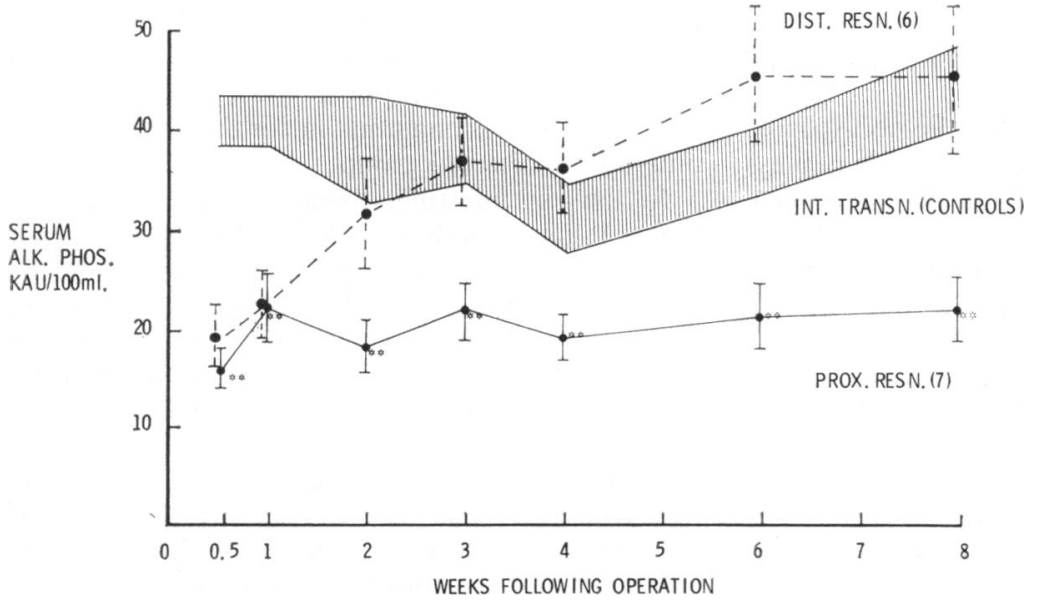

Fig 4 Serum alkaline phosphatase levels (KAU/100 ml-means $\pm S E M)$ following two-thirds proximal $(n=7)$ or distal $(n=6)$ small bowel resection compared with results in seven rats with intestinal transection (controls). The results for the proximal resection group were significantly less than control values $(* *=\mathrm{P}<0.01)$ at every time interval between 0.5 and eight weeks after operation. 
neither fatty infiltration of hepatocytes as occurs in impaired nutrition nor inflammatory cell infiltration.

\section{Discussion}

These results show that following extensive small bowel resection, both in the rat and in man, BSP excretion is temporarily impaired. Furthermore, in patients with intestinal resection, there may be other changes in hepatocellular function associated with mild to moderate fatty change in the liver.

In previous case reports of patients with extensive small bowel resection, fatty liver, with or without hepatic atrophy (Doolan, Kyle, Hess, and Phelps, 1951; Linder, Jackson, and Linder, 1953; Martin, Pattee, Gardner, and Marien, 1953; Arends, Nieweg, and Engelhardt, 1954; Harrison and Booth, 1960; Levin, Zamcheck, and Gottlieb, 1961), increased BSP retention (Jarnum, Schwartz, Thing, and Thorsøe, 1961), and evidence of hepatocellular dysfunction (Kositchek and Rabwin, 1950; Chodoff, 1950; Jackson, Linder, and Berman, 1951; Jarnum et al, 1961; Heaton, 1965; Windsor, Fejfar, and Woodward, 1969) have all been described. However, many of these patients died from cachexia as a result of postresection malabsorption and the fatty change. Hepatic atrophy, and hepatocellular dysfunction may well have been caused by inanition rather than as a consequence of resection per se.

In the few previous studies of liver structure and function following small bowel resection in experimental animals, there has been no consistent pattern of results (Derblom et al, 1962; Nygaard, 1968; Schwartz, Varco, and Buchwald, 1971). Derblom et al (1962) did note impaired uptake of ${ }^{131}$ I-labelled Rose Bengal after resection in the rat. However, they studied dye clearance at only one time (two months) after operation, and, although BSP clearance generally correlates well with Rose Bengal uptake (Nordyke and Blahd, 1959), our results show that the abnormal BSP clearance persisted for only three to four weeks after resection.

The present results also show that the non-specific effects of surgery and anaesthesia transiently depress BSP clearance in the rat as in man (Tagnon, Robbins, and Nichols, 1948). Nevertheless, small bowel resection caused further significant impairment of BSP clearance, particularly after removal of the distal small bowel.

The mechanism for the impaired BSP clearance is not certain, but reduced portal blood flow and changes in bile salt metabolism which may accompany intestinal resection could both affect excretion of the dye. The mesenteric contribution to the portal vein is reduced immediately after extensive resections, but, as the mucosa of the residual small bowel regenerates some two to four weeks after surgery (Dowling and Booth, 1967), there is a parallel increase in intestinal blood flow which should minimize any reduction in portal venous return. However, since blood flow to the ileum is either the same (Goodhead, 1969) or is less (Geber, 1960; Grim, 1963) than that to jejunum, changes in portal blood flow cannot account for the greater BSP retention seen after distal resection. This may be explained by loss of bile salts which occurs after ileal but not after jejunal resection (Dowling, Mack, and Small, 1970). Since bile salt infusions increase the maximal transport capacity (Tm) of BSP (O'Máille, Richards, and Short, 1966) the reduced hepatic bile salt secretion produced by ileectomy should impair BSP Tm.

In the experimental animals we have assessed the effects of intestinal resection uncomplicated by malnutrition or intercurrent disorders and as a result the histological appearances of the liver do not differ from those of control rats. In spite of the absence of overt hepatocellular damage we have shown that intestinal resection has a significant effect on liver function. In the patients the situation was more complicated in that postoperative recovery was generally slow and four of the six patients lost weight rapidly. Thus it is hardly surprising that the patients showed moreevidence of hepaticdysfunction than the experimental animals. The functional changes may be correlated with the histological appearances of the liver biopsies and in particular with the centrilobular fatty change which is a common non-specific response to many liver insults (Waterlow, Cravioto, and Stephen, 1960).

The changes in rat serum alkaline phosphatase following small bowel resection have not been previously recorded and may be due to removal of the intestinal brush border isoenzyme. In one previous study the authors state that liver function tests were 'essentially identical' in control and ileectomized rabbits (Schwarz et al, 1971) but in fact the mean serum alkaline phosphatase levels fell from 15.8 King Armstrong units in control animals to 3.6 units in the resected group.

In the rat intestine, tissue AP levels are much higher in jejunum than in ileum, the enzyme activity falling exponentially from proximal to distal intestine (Harrison and Webster, 1971). Since the intestinal isoenzyme is a major component of serum AP in the rat, it is not surprising that jejunectomy should depress the serum AP levels more than ileal resection, and it is of interest that the subsequent ileal mucosal hyperplasia, with parallel increases in tissue alkaline phosphatase (Gleeson, Dowling, and Peters, 1972) are insufficient to restore the serum AP to normal. The more modest mucosal hyperplasia seen in the 
jejunum after distal resection is also associated with increased tissue alkaline phosphatase activity, but here the mucosal regeneration restored serum AP levels to normal two to four weeks after resectionthe time when compensatory changes have fully developed in the residual intestine (Dowling and Booth, 1967). Serum AP levels appear to be closely related to concentrations of AP in the upper small intestine and may therefore provide an indirect marker of intestinal mucosal regeneration following ileal resection in the rat.

We wish to thank Drs J. Whitfield and D. Moss from the Department of Chemical Pathology for their advice and assistance with the serum enzyme determinations, Professor C. V. Harrison from the Department of Morbid Anatomy for advice on liver histology, Mr K. Modha for technical assistance, and Mrs Hazel Creed who kindly typed the script. Financial support from the Commonwealth Scholarship Commission (MCG) and from the MRC to the Intestinal Malabsorption Group (R.H.D.) is gratefully acknowledged.

\section{References}

Arends, A., Nieweg, H. O., and Engelhardt, J. (1954). Nutritional liver disease due to impaired absorption. Acta med. scand. 150, 163-168.

Barron, J., Frame, B., and Bozalis, J. R. (1969). A shunt operation for obesity. Dis. Colon Rect., 12, 115-119.

Bondar, G. F., and Pisesky, W. (1967). Complications of small intestinal short circuiting for obesity. Arch. Surg., 94, 707-716.

Booth, C. C., Evans, K. T., Menzies, T., and Street, D. F. (1959) Intestinal hypertrophy following partial resection of the small bowel in the rat. Brit. J. Surg., 46, 403-410.

Chodoff, R. J. (1950). Mesenteric vascular occlusion: case report of successful resection of all but eight inches of jejunum and ileum. Ann. Surg., 131, 440-444.

Derblom, H., Nylander, G., and Olerud, S. (1962). Absorption and liver function following extensive resection of the small intestine in the rat. Acta chir. scand., 123, 57-66.

Doolan, P. D., Kyle, L. H., Hess, W., and Phelps, E. (1951). Gastrocolostomy: clinical observations and experimental studies. Gastroenterology, 18, 566-578.

Dowling, R. H., and Booth, C. C. (1967). Structural and functional changes following small intestinal resection in the rat. Clin. Sci., 32, 139-149.

Dowling, R. H., Mack, E., and Small, D. M. (1970). Effects of controlled interruption of the enterohepatic circulation of bile salts by biliary diversion and by ileal resection on bile salt secretion, synthesis, and pool size in the rhesus monkey. $J$. clin. Invest., 49, 232-242.

Geber, W. F. (1960). Quartitative measurement of blood flow in various areas of small and large intestine. Amer. J. Physiol., 198, 985-986.

Gleeson, M. H., Dowling, R. H., and Peters, T. J. (1972). Biochemical changes in intestinal mucosa after experimental small bowel by-pass in the rat. Clin. Sci., 43, 743-757.

Goodhead, B. (1969). Distribution of blood flow in various selected areas of small and large intestine in the dog. Amer. J. Physiol., 217, 835-837.

Grim, E. (1963). The flow of blood in mesenteric vessels. In Handbook of Physiology, Sect. 2, Circulation, edited by W. F. Hamilton and P. Dow, Vol. II, pp. 1439-1456. American Physiological Society, Washington, D.C.

Harrison, D. D., and Webster, H. L. (1971). Proximal to distal variations in enzymes of the rat intestine. Biochim. biophys. Acta, 244, 432-436.
Harrison, R. J., and Booth, C. C. (1960). Massive resection of the small intestine after occlusion of the superior mesenteric artery. Gut, 1, 237-241.

Heaton, K. W. (1965). Liver dysfunction with jaundice in a case of severe malnutrition and malabsorption. Postgrad. med. J., 41, 573-574.

Humphreys, S. R., Dickson, E. R., Bagenstoss, A. H., and McGill, D. B. (1972). Cirrhosis, liver failure and death after jejunoileal anastomosis. (Abstr.) Gastroenterology, 62, 166.

Jackson, W. P. U.. Linder, G. C., and Berman, S. (1951). Small gut insufficiency following intestinal surgery. S. Afr. J. clin. Sci., 2, 70-112.

Jarnum, S., Schwartz, M., Thing, E., and Thorsøe, H. (1961). Extensive resection of the small intestine: a case report. Acta chir. scand., 122, 428-437.

Koenemann, L. C., and Ceballos, R. (1966). Massive hepatic necrosis following portacaval shunt: report of two cases and considerations of liver hemodynamics after shunt. J. Amer. med. Ass., 198, 138-142.

Kositchek, R. J., and Rabwin, M. H. (1950). Massive resection of the small bowel for adenocarcinoma of the jejunum. Amer. $J$. dig. Dis., 1st ser., 17, 13-17.

Levin, H., Zamcheck, N., and Gottlieb, L. S. (1961). Six year survival following massive intestinal resection with eventual potassium depletion nephropathy. Gastroenterology, 40, 818-822.

Lewis, L. A., Turnbull, R. B., Jr., and Page, I. H. (1962). "Shortcircuiting" of the small intestine: effect on concentration of serum cholesterol and lipoproteins. J. Amer. med. Ass., 182, 77-79.

Linder, A. M., Jackson, W. P. U., and Linder, G. C. (1953). Small gut insufficiency following intestinal surgery. III. Further clinical and autopsy studies of a man surviving three-and-a-half years with seven inches of small intestine. S. Afr. J. clin. Sci., 4, $1-22$.

Martin, J. R., Pattee, C. J., Gardner, C., and Marien, B. (1953). Massive resection of the small intestine. Canad. med. Ass. J., 69, 429-433.

Maxwell, J. G., Richards, R. C., and Albo, D., Jr. (1968). Fatty degeneration of the liver after intestinal bypass for obesity. Amer. J. Surg., 116, 648-652.

Nordyke, R. A., and Blahd, W. H. (1959). Blood disappearance of radioactive rose Bengal-rapid simple test of liver function. J. Amer. med. Ass., 170, 1159-1164.

Nygaard, K. (1967). Resection of the small intestine in rats. III. Morphological changes in the intestinal tract. Acta chir. scand., 133, 233-248.

Nygaard, K. (1968). Nutrition and absorption after resections and by-pass operations on the small intestine in rats. Acta chir. scand., 134, 63-77.

O'Máille, E. R. L., Richards, T. G., and Short, A. H. (1966). Factors determining the maximal rate of organic anion secretion by the liver and further evidence on the hepatic site of action of the hormone secretin. J. Physiol. (Lond.), 186, 424-438.

Payne, J. H., DeWind, L. T., and Commons, R. R. (1963). Metabolic observations in patients with jejunocolic shunts. Amer. J. Surg., 106, 273-289.

Poulik, M. D. (1957). Starch gel electrophoresis in a discontinuous system of buffers. (Letter). Nature (Lond.), 180, 1477-1479.

Schwartz, M. Z., Varco, R. L., and Buchwald, H. (1971). Liver function and morphology following distal ileal excision in the rabbit. Surg. Forum, 22, 355-356.

Seligson, D., Marino, J., and Dodson, E. (1957). Determination of sulfobromophthalein in serum. Clin. Chem., 3, 638-645.

Shagrin, J. W., Frame, B., and Duncan, H. (1971). Polyarthritis in obese patients with intestinal bypass. Ann. intern. Med., 75, 377-380.

Shibata, H. R., MacKenzie, J. R., and Long, R. C. (1967). Metabolic effects of controlled jejunocolic bypass. Arch. Surg., 95, 413-428.

Tagnon, H. J., Robbins, G. F., and Nichols, M. P. (1948). The effect of surgical operations on the bromsulfalein-retention test. New Engl. J. Med., 238, 556-560.

Touloukian, R. J., and Spencer, R. P. (1972). Ileal blood flow preceding compensatory intestinal hypertrophy. Ann. Surg., 175, 320-325.

Waterlow, J. C., Cravioto, J., and Stephen, J. M. L. (1960). Protein malnutrition in man. Advanc, protein Chem., 15, 131-238.

Windsor, C. W. O., Fejfar, J., and Woodward, D. A. K. (1969). Gastric secretion after massive small bowel resection. Gut, 10, 779-786. 